\title{
Accounting for bitcoins in light of IFRS and tax aspects*
}

\author{
Marta Cristina Pelucio-Grecco ${ }^{1}$ \\ (D) https://orcid.org/0000-0001-6994-4219 \\ Email: marta.pelucio@fipecafi.org \\ Jacinto Pedro dos Santos Neto ${ }^{1}$ \\ (D) https://orcid.org/0000-0002-2106-8800 \\ Email: jacinto.neto@fipecafi.edu.br \\ Diego Constancio' ${ }^{1}$ \\ (iD) https://orcid.org/0000-0002-2659-0884 \\ Email: diego.constancio@fipecafi.edu.br \\ ${ }^{1}$ Faculdade Fipecafi, São Paulo, SP, Brazil
}

Received on 12.04.2018 - Desk acceptance on 12.20.2018 - $2^{\text {nd }}$ version approved on 09.01.2019 - Ahead of print on 01.31.2020 Associate Editor: Eliseu Martins

\begin{abstract}
This essay presents recommendations in regard to accounting for operations that involve bitcoins, in compliance with the International Financial Reporting Standards (IFRS), and analyzes their main tax aspects. There is no specific pronouncement on the part of the International Accounting Standards Board (IASB) or from the Brazilian Accounting Pronouncements Committee (CPC) regarding the accounting treatment to be applied in operations that use these currencies. Bitcoin is of interest to economists as a virtual currency with the potential to disrupt existing payment systems and even monetary systems. This essay offers a contribution for standard-setters and the tax authority (fisco) by providing the basis for possible guidelines to be issued on the accounting treatment of bitcoin operations, as well as by defining the appropriate tax treatment; in addition, it makes a contribution for accounting professionals by suggesting the accounting policy to be adopted in these operations. Here, the analysis of the characteristics of bitcoins is compared with the guidelines and concepts of IFRS, in order to elaborate the recommendation for accounting treatment, and it suggests that the most adequate procedure would be that of foreign currency, which would go against the tax treatment adopted up until now by the Brazilian Internal Revenue Service (Receita Federal) or the Internal Revenue Service (IRS) of the United States of America (USA), which suggest treating virtual currencies as goods and not as currencies. It warrants mentioning that this contradiction may cause tax risks for taxpayers.
\end{abstract}

Keywords: IFRS, bitcoin, cryptocurrencies, taxes.

Correspondence address

Marta Cristina Pelucio-Grecco

Faculdade Fipecafi

Rua Maestro Cardim, 1170 - CEP 01323-001

Bela Vista - São Paulo - SP - Brazil

*Article presented at the V Meeting of Professional Masters in Business Administration, São Paulo, SP, Brazil, November of 2018. 


\section{INTRODUCTION}

Throughout history, technology has provided solutions to the different problems of society and the financial innovation of virtual currencies, such as bitcoin, could resolve persistent monetary problems, such as inflation and transaction costs (Boff \& Ferreira, 2016). According to research on the impact on the banking sector and on retail conducted by PricewaterhouseCoopers $(\mathrm{PwC})$, most users state that cryptocurrencies are going to redefine banks as we know them and that their banking experience would be improved if they had greater access to them (PricewaterhouseCoopers [PwC], 2015).

According to Ulrich (2016), in the first half of 2016, trades in bitcoins on the main exchanges exceeded the volume traded in gold on the Brasil, Bolsa, Balcão (B3) exchange. Worldwide, gold still exceeds bitcoin, with a daily volume of US $\$ 20$ billion against US $\$ 1.5$ billion in the virtual currency (Cieśla, 2017). Bitcoin is of interest to economists as a virtual currency with the potential to disrupt existing payment systems and even monetary systems (Böhme, Christin, Edelman, \& Moore, 2015).

The debates concerning the economic, financial, and legal aspects of bitcoin have intensified recently, but as yet there is no agreement regarding the classification and treatment of bitcoin (Balcilar, Bouri, Gupta, \& Roubaud, 2017). Souza (2014) stresses the need for accounting professionals to be able to deal with the new ways of doing business, as in the case of bitcoin use. Ram (2016) identified the key characteristics of bitcoin, qualitatively analyzing the relevant literature on the topic.

The use of virtual currency already forms part of the day-to-day of companies, however there is no specific pronouncement on the part of the International Accounting Standards Board (IASB), which issues the International Financial Reporting Standards (IFRS), or from the Brazilian Accounting Pronouncements Committee (CPC), the body responsible for issuing accounting pronouncements in Brazil, regarding the accounting treatment to be applied in operations that use these currencies.

The general aim of this essay is to present recommendations in regard to accounting for operations that involve bitcoins, in compliance with IFRS, based on the characteristics identified by Ram (2016), also analyzing their main tax aspects.

The hope is to offer a contribution (i) for Brazilian standard-setters, by providing support in the possible issuance of guidance for the accounting treatment of bitcoin operations; (ii) for accounting professionals, by providing support in the accounting policy to be adopted in these operations; and (iii) for the tax authority ( $i s c o$ ), by providing support in the definition of the tax treatment of these operations.

\section{CURRENCY}

The word money is used in a generic way, revealing the numerous meanings that it can take (Mishkin, 2011). However, for economists, this word takes on a specific meaning. Money is an item or something verifiable that is accepted as a form of payment for goods, services, or debts (Mishkin, 2011). So, in order for it to have this characteristic, according to Jevons (1875, as cited in Ostroy \& Starr, 1990), money must perform the following functions: (i) a means of exchange; (ii) a common measure of value; (iii) a standardized exchange value; and (iv) a store of value.

According to Mishkin (2011), as the definition of money is broad, it covers items that are accepted as a form of payment in general. In order to avoid theoretical confusion, there is a need to specify the item of exchange and, in this case, currency, taking the form of dollar notes and widely used metal alloy objects, clearly fits the definition of a type of money.
In regard to currencies, these can classically be called commodity money, which has an intrinsic value, or fiat money, which has no intrinsic value. Radford (1945, as cited in Tan \& Low, 2017) explains that even cigarettes, if they had the characteristics of standardization, portability, durability, divisibility, and wide acceptance in the market, could be considered commodity money, and so representatives of money, as has in fact occurred in situations involving prisoners of war.

\subsection{Cryptocurrencies and Virtual Currencies}

Cryptocurrencies are a means of exchange, like the dollar in the United States of America (USA) or the real in Brazil; but they do not have intrinsic value, in that they are not backed by another good, such as gold. Unlike the dollar, however, cryptocurrency has no physical form and, currently, it is not supported by any government or 
legal entity. Moreover, its supply is not determined by a central bank and its network is totally decentralized, with all the transactions being carried out by the users of the system, and thus it does not fit the classic definition of currency, as indicated.

One important reason behind the emergence of virtual currencies was the desire to create a system that enables quick and cheap transactions, with no need for a third party, such as a bank or financial intermediary. This is not a completely new idea and is based on the concept of electronic currency (Chaum, 1983).

\subsection{Bitcoin}

Bitcoins are a form of online payment based on free software (Balcilar et al., 2017); that is, their source code is open to the public and available for free distribution, as well as ensuring the preservation of copyrights and the modification of codes to constantly improve the software attributes (Arief, Gacek, \& Lawrie, 2004). Bitcoin was the precursor of cryptocurrencies, emerging in 2009, and its creation has been attributed to Satoshi Nakamoto, whose real name is unknown (Ciaian, Rajcaniova, \& Kancs, 2016).

For Boff and Ferreira (2016), cryptocurrencies can cause social and economic effects, such as the universalization of financial services for the whole population, lower transaction costs, and user protection against inflation. Regalado (2015) highlights that the attraction of a return without transaction costs is one of the determining factors for using bitcoins.

Essentially, bitcoins have no physical form, are not backed by any good, and are not guaranteed, nor regulated, by any government or central bank, instead being decentralized and depending on a sophisticated protocol, which uses cryptography alone to control transactions, manage supply, and prevent harmful actions (Balcilar et al., 2017). These trades are stored digitally and recorded in a shared electronic ledger, organized by means of a technology with various blocks of transaction information, called the blockchain (Balcilar et al., 2017).

Mining is a process for validating blockchain transactions, relying on computing power to solve complex mathematical algorithms (Boff \& Ferreira, 2016). Users of the mining systems that validate transactions are called miners, which are essentially the computers of the network users themselves, and, after they validate blockchain trades, the users who solve the mathematical algorithms are rewarded with bitcoins (Boff \& Ferreira, 2016).

The model has been technically designed so that the currency supply will develop at a predictable rate and the algorithms to be solved in order to receive new bitcoins become more and more complex, requiring more computing resources. The maximum number of bitcoins 1 will reach 21 million (Boff \& Ferreira, 2016).

Ram (2016) identified 17 characteristics of bitcoin: $\mathrm{C} 1$ - all the transactions are recorded in a digital public record to ensure their authenticity and non-duplication; $\mathrm{C} 2$ - it is a decentralized and non-regulated currency; C3 - it only exists digitally; C4 - it is easily transferred; $\mathrm{C} 5$ - there are different prices on different exchanges; C6 - it constitutes a means of payment for buying goods and services; $\mathrm{C} 7$ - it can be used for speculative purposes; C8 - it can be used as a means for accumulating value; C9 - it can be produced (mining); C10 - it presents high price volatility; C11 - its supply is limited; $\mathrm{C} 12$ - it has no intrinsic value; $\mathrm{C} 13$ - it is not tied to macroeconomic variables (it is not indexed); $\mathrm{C} 14$ - it is tradeable in the ordinary course of business; $\mathrm{C} 15$ - it can be considered a type of currency or contractual right to receive a fixed or determinable amount of currency; C16 - it can be seen as an asset used in the production or supply of goods and services; and C17 - it is similar to a consumable, used in facilitating a transaction.

\section{ACCOUNTING TREATMENT OF BITCOINS}

In compliance with the conceptual structure of IFRS, the useful accounting information generated should be relevant and faithfully represent the patrimonial and financial situation of an entity (International Accounting Standards Board [IASB], 2019). The general principle of IFRS takes into consideration essence over form. Based on the conceptual structure of IFRS, bitcoin should be classified as an asset, since it is a resource controlled by the entity, derived from past events and from which economic benefits are expected to be obtained in the future. But what type best represents the essence of this asset?

In the process of choosing and applying accounting policies, in compliance with IAS 8 - Accounting Policies, Changes in Accounting Estimates, and Errors, the entity should first verify the existence of a standard or interpretation that specifically addresses the event under analysis. In the event of no specific standard, the entity's management should define the accounting policy to be 
adopted, based on standards or interpretations that treat a similar event and on definitions and concepts of the conceptual structure (IASB, 2019).

No accounting standard has yet been issued by the IASB that specifically treats cryptocurrencies, which have been treated by the International Financial Reporting Interpretations Committee (IFRIC), the committee for interpreting IFRS. In March of 2019, the IFRIC discussed the recording of cryptocurrencies in accounts and the trend indicated is to recognize them as stock for the exchanges and as intangibles for the bitcoin holders. The Australian Accounting Standards Board (AASB, 2018) has the same understanding as the IFRIC.

Tan and Low (2017) agree with the understanding of the IFRIC and of the AASB for exchanges; however, unlike those bodies, they suggest recording the currency for the others. Tan and Low (2017) highlight that the position of the tax authorities, as in the case of the USA, of treating virtual currency as property is even more confusing for accountants in search of a guide for recording them.

The discussions on cryptocurrencies include their recognition as cash and cash equivalents, financial instruments, or intangibles, due to their characteristic of lacking physical substance, which eliminates the possibility of assets such as fixed assets (AASB, 2018; IFRIC, 2019; Tan \& Low, 2017).

Ram (2016) built a conceptual structure for accounting for bitcoins based on the theories of neoliberalism and stewardship, by means of interviews with experts to build a map for accounting for bitcoin, which was validated by means of a survey. Ram (2016) concluded that bitcoins should be measured at fair value based on the business model and on the bitcoin holder's intention.

Unlike the analysis by Ram (2016), which focuses on measuring bitcoin, we analyze its characteristics in order to choose and apply the appropriate accounting policy, in compliance with IAS 8, identifying what standard treats an event that is most similar to bitcoin. For the analysis of similar events, essence over form cannot be overlooked. Essence is something that is common in entities of the same nature and differentiates them from others. To find the essence, we must analyze the characteristics of the entity being studied, because it is through its characteristics that we can define its essence (Aquino, 1995).

Based on the characteristics of bitcoin presented by Ram (2016), we analyzed the recording of bitcoins by their holders, focusing our analysis on the possible assets without physical substance, in line with the IFRIC and the AASB, namely: (i) foreign currency; (ii) financial instruments; or (iii) intangible assets. Our analysis is interpretative, considering the definitions of IFRS for these assets, namely: (i) foreign currency is different from functional currency; ii) cash includes cash holdings and available bank deposits; (iii) financial instruments are any contract that gives rise to a financial asset for the entity and a financial liability or equity instrument for another entity; and (iv) intangibles are identifiable non-monetary assets with no physical substance (IASB, 2019).

Characteristics $\mathrm{C} 1, \mathrm{C} 9$, and $\mathrm{C} 11$ are specific to bitcoin and have no similarity with any of the assets classifications studied, since in none of the cases is there a public digital record nor can they be produced through mining, and they also do not have a limited supply. That is, in 3 of the 17 characteristics (around 18\%), something new and unforeseen is concerned.

Around $35 \%$ of the characteristics studied (C3, C8, $\mathrm{C} 12, \mathrm{C} 14, \mathrm{C} 16$, and C17) fit the 3 classifications studied, since currencies, financial instruments, and intangibles can be used as means to accumulate value, they can exist virtually, they have no intrinsic value, they are tradeable in the ordinary course of business, and they can be used or consumed in the production or supply of goods or services. Currencies have physical form, but they also exist digitally, since they can take the form of electronic currencies. Electronic currencies constitute a monetary value, represented by a credit over the issuer, they are stored electronically, and accepted as a form of payment (e.g. debit card transactions). Currencies have no intrinsic value (as in the era when they were minted in silver or gold) and they are not representative (they are not backed by any good, due to the end of the Bretton Woods Agreement); their value derives merely from government decree (Mankiw, 2009). Financial instruments are contracts that give rise to a financial asset, may not have a physical form, and can be traded in electronic auctions. Thus, despite the fact that financial instrument may have a physical contract, they can also exist digitally and do not have intrinsic value. Their value is representative, since, in the case of an asset, they represent the right to receive that asset. Intangibles are assets with no physical substance, and thus they exist virtually and have no intrinsic value.

Characteristics $\mathrm{C} 2$ and $\mathrm{C} 13$ only fit intangibles (around $12 \%)$, since both currencies and financial instruments are regulated. The government cannot control bitcoin and also cannot control intangibles, since they are not influenced by macroeconomic variables, such as interest rates, gross domestic product (GDP), and fiscal policy. Both financial 
instruments and (conventional) currencies are affected by those macroeconomic variables.

Characteristics C4, C6, and C15 only adhere to currency (around 18\%), since financial instruments and intangible assets are not easily transferable and are not a form of payment for buying goods and services. A numerical monetary unit and standardized measure of the value of goods, services, and other market transactions is concerned, which is an exclusive characteristic of currencies and present in bitcoin.

Characteristics C5, C7, and $\mathrm{C} 10$ are not adherent to intangible assets (around 18\%), since only financial instruments and currencies can have different prices in stock exchanges, and they may generate financial arbitrage, be used for speculative purposes, and have high price volatility.

According to Figure 1, the classification of bitcoin as a financial instrument is adherent in 10 of the 17 characteristics studied, resulting in $59 \%$ adherence, where no characteristic was identified as exclusive to this type of asset. As intangibles are adherent in 7 of them, there is $41 \%$ adherence, where 2 of them are exclusive to this type of asset. Classification as currency is adherent in 13 characteristics, resulting in $76 \%$ adherence, where 3 of them are exclusive to this type of asset. Thus, the suggestion is to recognize this asset as foreign currency, whose classification is most adherent, and able to represent it most faithfully.

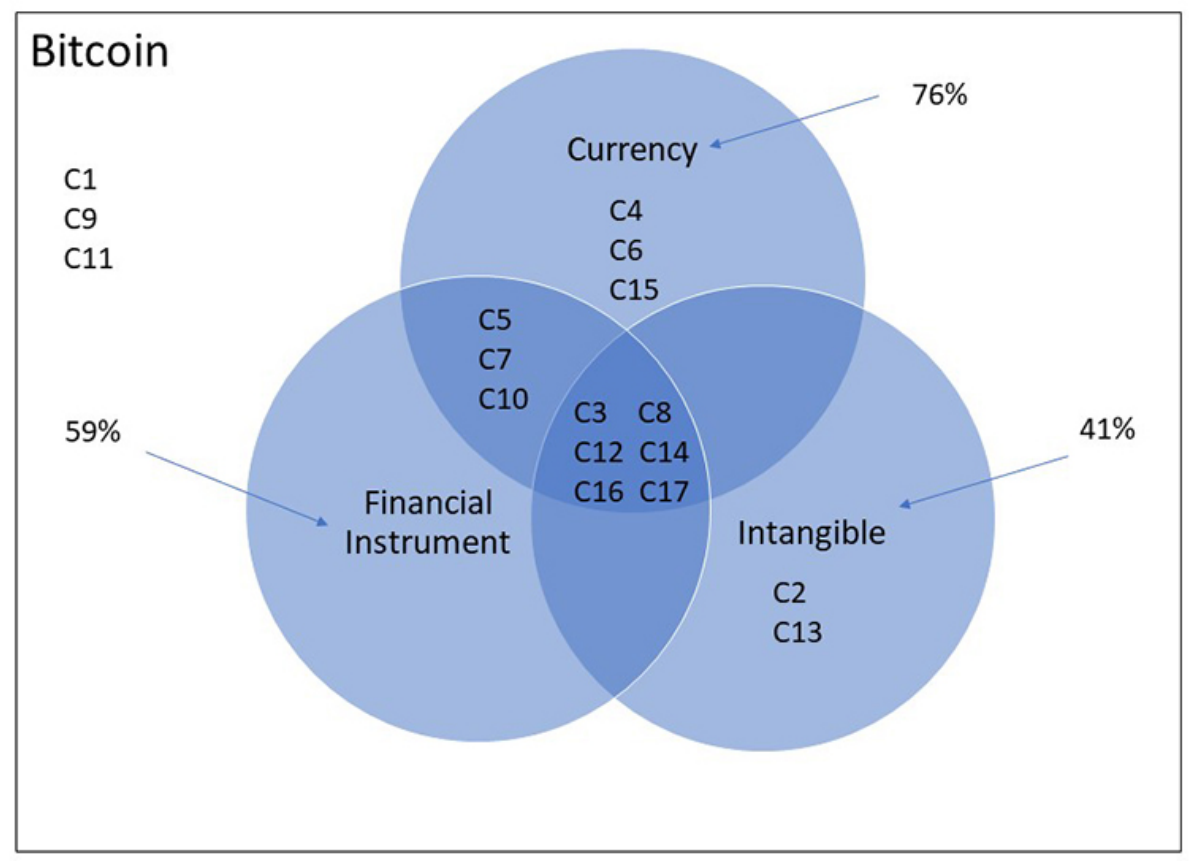

Figure 1 Adherence of bitcoin as currency, a financial instrument, or an intangible.

Source: Elaborated by the authors.

If considering bitcoin a currency, it should be treated as foreign currency, where IAS 21 - The Effects of Changes in Foreign Exchange Rates should be applied. Bitcoin should initially be recognized in the accounts by the functional currency, by applying the quotation on the date of the transaction, and it should be classified in current assets as cash. At the end of each period, the position in foreign currency - in this case, bitcoins - should be converted into functional currency, using the quotation on the closing date. The variations derived from the variation in the exchange rate for bitcoin should be recognized in the result in the same way as other foreign currencies. 


\section{TAX ASPECTS OF BITCOINS}

Campos (2015) highlights the need for the public authorities to regulate bitcoin, in order to avoid tax evasion, possible ties with the illegal market, and to protect consumer rights. Some researchers state that the cybernetic world transcends geographical and national borders, therefore it may not be compatible with the existing tax framework and attempts should be made to develop new taxes for transactions that occur in cyberspace (Azam, 2012). For Bal (2014), the European Union and the U.S. Treasury consider that the best way to address electronic commerce is through an approach that adopts and adapts the existing principles, instead of imposing new or additional taxes.

According to Ly (2013), there are 2 main ways for bitcoins to generate income. First, the value of a bitcoin fluctuates, and bitcoins can be sold for higher values than the original purchase price, thus generating a profit for the seller. Second, bitcoins can be received by vendors as payment for goods and services and, therefore, should be taxed by the sale of the merchandise, just like a sale mediated by a conventional fiduciary currency. For Bal (2014), there are 3 main types of activities involving virtual currencies that may be relevant for income tax purposes: (i) the creation of virtual currency (through mining and concluding tasks); (ii) holding virtual currency that has appreciated in value; and (iii) exchanges.

Exchanges can give rise to 2 types of income: (i) real income (when virtual currencies and items are sold for money in the legal sense); and (ii) virtual income (when goods and services are exchanged for virtual money). Also according to $\mathrm{Bal}$ (2014), the tax treatment of income expressed in virtual currency is more problematic. Although virtual currencies are designed to perform the same functions as traditional currencies, they cannot be considered money in the legal sense, but are duly characterized as assets.

According to Simons (1983), all the increase in wealth should be taxed. Hence, regardless of the origin of profit, whether generated in the real world or in the virtual world, it should be taxed. Thus, in the USA, the Internal Revenue Service (IRS) has issued its opinion and considered bitcoins to be a good, and therefore subject to all the tax principles applicable to goods.

Up until now, the Brazilian tax authority (fisco) has not issued any opinion in relation to the tax treatment of bitcoins by legal entities, merely requiring information to be sent via RFB Normative Instruction n. 1,888 (2019). However, in the questions and answers of the Brazilian Internal Revenue Service on income tax for individual taxpayers in 2017, it is stated that virtual currencies (e.g. bitcoins), even though they are not considered currencies in the terms of the current regulatory framework, should be declared in the Assets and Rights Form as "other goods," since they can be compared to a financial asset and should be declared by acquisition value. Thus, like any asset, bitcoins are subject to taxation at the time of their sale as capital gains and a Realization of Capital Gains Declaration should be presented. According to De Morais \& Brandão (2015), the production of cryptocurrencies is not subject to tax on industrialized products (IPI), because there is no legal provision in this sense and because, even if there was, the occurrence would not be constitutional, since they do not result from an industrial process.

Bitcoin would not be subject to tax on foreign exchange financial operations (IOF), given that it does not constitute a national or foreign currency, at least in legal terms. However, IOF could be applicable on bonds and securities, if the value of the bitcoin was represented in the form of some security. However, for some authors, charging IOF on foreign exchange would be possible via the elaboration of a law that considers this specific taxation hypothesis (Borges \& Silva, 2016).

Also according to De Morais \& Brandão (2015), charging Tax on the Circulation of Goods and Services (ICMS) could be valid, since whoever buys a bitcoin from a third party is acquiring a good for themselves. ICMS is a non-cumulative tax, offsetting the value due in each transaction or payment with the amount charged previously, in which a tax invoice or tax coupon should be issued. In contrast, Pereira (2016) suggests that, in the case of exchanging bitcoin for money, ICMS should be applied, since the exchange is carried out between private parties with no commercial nature. 


\section{CONCLUDING REMARKS}

Bitcoin is an innovate asset and its characteristics do not appear to fit the existing classifications, making the accounting recognition of this asset a challenging task.

By observing the main characteristics of bitcoin and comparing them with the most probable classifications, greater adherence to classification as foreign currency can be verified, which is consistent with its essence and with the aim of its creation to carry out the role of a currency. Virtual currencies may not have all the characteristics of a classic currency; however, they have essential common characteristics, such as a means of exchange, a common measure of value, and a standardized exchange value. The divergences between virtual currencies and classic ones are: (i) not having a central bank; and (ii) not having a physical form. But virtual currencies present an extremely regulated form of distribution and creation, thus generating credibility.

It is important for accounting standard-setters and tax authorities to engage in efforts to adequately define the treatment for bitcoins, to avoid uncertainties among their holders and the users of accounting information, as well as tax risks.

\section{REFERENCES}

Aquino, T. (1995). O ente e a essência (Coleção Os Pensadores). São Paulo, SP: Nova Cultural.

Arief, B., Gacek, C., \& Lawrie, T. (2004). The many meanings of open source. IEEE Software, 21(1), 34-40.

Australian Accounting Standards Board. (2018). Digital currency: a case for standard setting activity. Retrieved from https:// www.ifrs.org/-/media/feature/meetings/2018/may/eeg/ap2ddigital-currencies-paper.pdf

Azam, R. (2012). The political feasibility of a global e-commerce tax. University of Memphis Law Review, 43(3), 711-754.

Bal, A. M. (2014). Taxation of virtual currency. Leiden, Netherlands: Leiden University.

Balcilar, M., Bouri, E., Gupta, R., \& Roubaud, D. (2017). Can volume predict bitcoin returns and volatility? A quantilesbased approach. Economic Modelling, 64, 74-81.

Boff, S. O., \& Ferreira, N. A. (2016). Análise dos benefícios sociais da bitcoin como moeda. Anuario Mexicano de Derecho Internacional, 16, 499-523.

Böhme, R., Christin, N., Edelman, B., \& Moore, T. (2015). Bitcoin: economics, technology, and governance. Journal of Economic Perspectives, 29(2), 213-238.

Borges, L. M., \& Silva, L. G. D. (2016). O regime jurídico tributário aplicável às criptomoedas. Florianópolis, SC: Conselho Nacional de Pesquisa e Pós-Graduação em Direito.

Campos, G. I. R. V. (2015). Bitcoin: consequências jurídicas do desenvolvimento da moeda virtual. Revista Brasileira de Direito, 11(2), 77-84.

Chaum, D. (1983). Blind signatures for untraceable payments. New York, NY: Plenum.

Ciaian, P., Rajcaniova, M., \& Kancs, D. A. (2016). The economics of Bitcoin price formation. Applied Economics, 48(19), 17991815.
Cieśla, K. (2017). Bitcoin trading volume. Retrieved from http:// bitcoinity.org/markets

De Morais, C. Y. A., \& Brandão, J. B., Neto. (2015). Tributação das operações com criptomoedas. Revista Jurídica Eletrônica da UFPI, 1(7), 41-60.

Instrução Normativa RFB (RFB Normative Instruction) n. 1,888, of May $3^{\text {rd }}$ of 2019. (2019). Establishes and rules on the obligation to provide information relating to operations carried out with cryptocurrencies to the RFB. Retrieved from http://www.normaslegais.com.br/legislacao/instrucaonormativa-rfb-1888-2019.htm

International Accounting Standards Board. (2019, January). The annotated issued IFRS standards. London, England: Author.

International Financial Reporting Interpretations Committee. (2019, March). IFRIC Update March 2019. Retrieved from https://www.ifrs.org/news-and-events/updates/ifric-updates/ march-2019/

Ly, M. K. M. (2013). Coining bitcoin's legal-bits: examining the regulatory framework for bitcoin and virtual currencies. Harvard Journal of Law \& Technology, 27, 587-608.

Mankiw, N. G. (2009). Macroeconomics. New York, NY: Worth.

Mishkin, F. S. (2011). The economics of money, banking, and financial markets. Boston, MA: Addison Wesley.

Ostroy, J. M., \& Starr, R. M. (1990). The transactions role of money. In B. M. Friedman, \& F. H. Hahn (Eds.), Handbook of monetary economics (Vol. 1, pp. 3-62). New York, NY: Elsevier.

Pereira, K. A. S. (2016). Bitcoin: uma análise jurídico-tributária da moeda virtual (Course Conclusion Monograph). Manaus, AM: Universidade Federal do Amazonas.

PricewaterhouseCoopers. (2015, September). Money is no object: understanding the evolving cryptocurrency market. Retrieved from https://www.pwc.com/us/en/industries/financialservices/library/cryptocurrency-evolution.html 
Ram, A. J. (2016). Accounting for the bitcoin: an initial perspective. Johannesburg, South Africa: University of the Witwatersrand.

Regalado, J. M. S. (2015). Determinantes da procura da bitcoin (Master's Dissertation). Porto, Portugal: Instituto Superior de Contabilidade e Administração do Porto.

Simons, H. (1983). Personal income taxation: the definition of income as a problem of fiscal policy. Chicago, IL: University of Chicago.
Souza, M. C. (2014). O uso de inteligência artificial no ensino da contabilidade (Master's Dissertation). São Paulo, SP: Universidade de São Paulo.

Tan, B. S., \& Low, K. Y. (2017). Bitcoin: its economics for financial reporting. Australian Accounting Review, 27, 220-227.

Ulrich, F. (2016, 7 de julho). Bitcoin supera o ouro no Brasil. Retrieved from http://www.infomoney.com.br/blogs/cambio/ moeda-na-era-digital/post/5288549/bitcoin-supera-ouro-brasil 
Marta Cristina Pelucio-Grecco, the author of the essay "Accounting for bitcoins in light of IFRS and tax aspects," published in volume 31, issue 83, doi: 10.1590/1808-057x201909110, of the Accounting \& Finance Review, MayAugust of 2020, detected inaccuracies in the data sent by the authors to the Review. The difference between the real data from the research and the data sent by the authors is minimal and does not affect the result published in the essay. Nonetheless, with the aim of maintaining the transparency and accuracy of the essay, we are publishing this erratum to make public the correct data used by the authors for the research.

\section{On page 279, where it reads (emphasis added):}

According to Figure 1, the classification of bitcoin as a financial instrument is adherent in $\mathbf{1 0}$ of the 17 characteristics studied, resulting in $\mathbf{5 9 \%}$ adherence, where no characteristic was identified as exclusive to this type of asset. As intangibles are adherent in 7 of them, there is $\mathbf{4 1 \%}$ adherence, where 2 of them are exclusive to this type of asset. Classification as currency is adherent in $\mathbf{1 3}$ characteristics, resulting in $\mathbf{7 6 \%}$ adherence, where 3 of them are exclusive to this type of asset. Thus, the suggestion is to recognize this asset as foreign currency, whose classification is most adherent, and able to represent it most faithfully.

\section{it should read (emphasis added):}

According to Figure 1, the classification of bitcoin as a financial instrument is adherent in 9 of the 17 characteristics studied, resulting in $\mathbf{5 3 \%}$ adherence, where no characteristic was identified as exclusive to this type of asset. As intangibles are adherent in $\mathbf{8}$ of them, there is $\mathbf{4 7 \%}$ adherence, where 2 of them are exclusive to this type of asset. Classification as currency is adherent in 12 characteristics, resulting in $\mathbf{7 1 \%}$ adherence, where 3 of them are exclusive to this type of asset. Thus, the suggestion is to recognize this asset as foreign currency, whose classification is most adherent, and able to represent it most faithfully.

\section{In Figure 1, where it reads (emphasis added):}

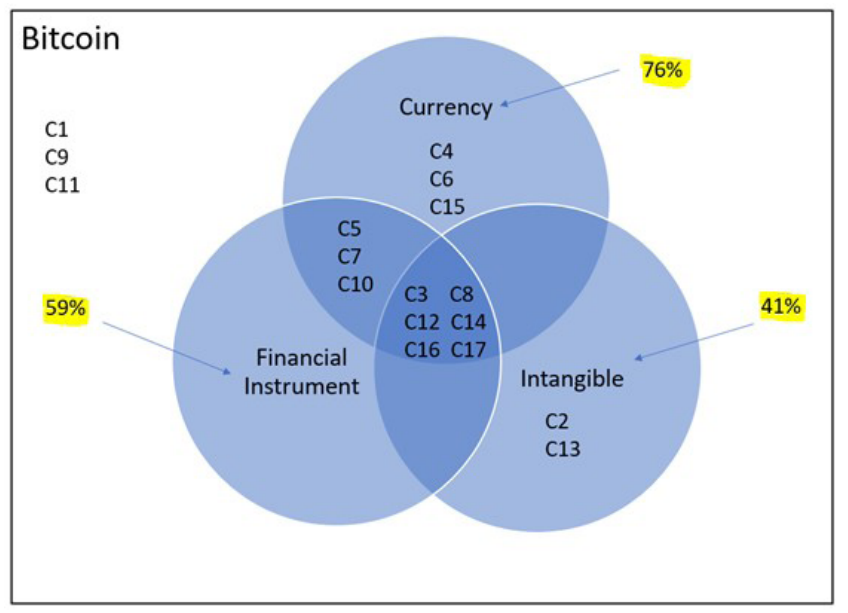

\section{it should read (emphasis added):}

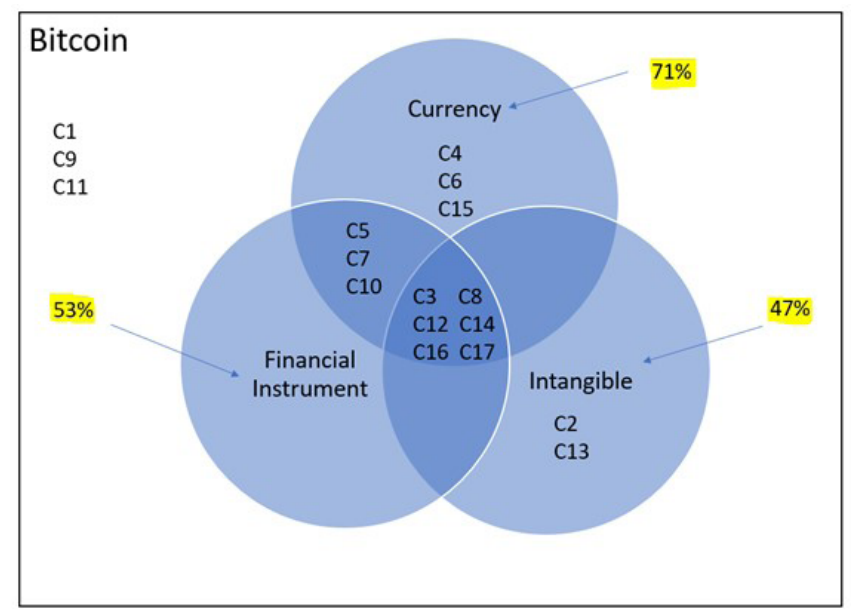

